International Journal of Business Management and Economic Review

Vol. 3, No. 05; 2020

ISSN: 2581-4664

\title{
THE INFLUENCE OF JOB EMBEDDEDNESS, LEADERSHIP AND MOTIVATION OF THE WORK ENGAGEMENT AND ITS IMPLICATIONS IN THE PERFORMANCE OF PT. BRI BANKS OF SIGLI
}

\author{
*Sella Diba, Amri and Teuku Roli Ilhamsyah Putra \\ Magister Manajemen, Universitas Syiah Kuala, Indonesia \\ http://doi.org/10.35409/IJBMER.2020.3197
}

\begin{abstract}
This research examines the effect of job embeddedness, leadership and motivation on work engagement and its implications for the performance of PT. BRI Bank Sigli Branch. The right research population is all employees of PT. BRI Bank Sigli Branch totaling 127 people. Sampling was done by census technique on all employees at PT. BRI Bank Sigli Branch. The research model was analyzed using Structural Equation Modeling (SEM) through the use of the Amos application. The results of this study prove that Job embeddedness influences work engagement, leadership also influences work engagement, work motivation influences work engagement, Job embeddedness influences organizational performance, Leadership influences organizational performance, Work motivation possessed by office employees affects organizational performance, Work engagement has an influence on improving organizational performance, work engagement mediates the influence of job embeddedness on organizational performance, work engagement mediates the influence of leadership on organizational performance, and work engagement mediates the effect of work motivation on organizational performance. The results of this study indicate that to ensure the performance of PT. BRI Bank Sigli Branch, focus must be given to increase work engagement through increased job embeddedness, leadership, and work motivation within the company. These findings contribute academically, especially in the renewal of the theory of causality and can be a reference for practical leaders, especially those in PT. BRI Bank Sigli Branch. The novelty of the results of this study lies in the combination of the previous causality research model, using new objects. The limitation of the study is the number of variables studied and the scope of the study.
\end{abstract}

Keyword: Job Embeddedness, Leadership, Motivation, Work Engagement, Organizational Performance.

\section{INTRODUCTION}

As a BUMN, PT. Bank BRI is one bank in Indonesia which has the largest assets engaged in financial services. Until now, PT. Bank BRI has a work unit of 4,447 units, consisting of 1 BRI Head Office, 12 Regional Offices, 12 Inspection Offices / SPI, 170 Branch Offices (domestic), 145 Supporting Branch Offices, 1 Special Branch Office, 1 New York Agency, 1 Caymand Island Agency, 1 Hong Kong Representative Office, 40 Cash Pay Offices, 6 Bank Mobile 


\section{International Journal of Business Management and Economic Review}

Vol. 3, No. 05; 2020

ISSN: 2581-4664

Offices, 193 P.POINT, 3,705 BRI UNIT and 357 Village Service Posts. Everything is integrated so that in operation it is expected that all can be solid to achieve the same goal of advancing and developing the company.

In order to improve the performance of PT. Bank BRI, it requires the management of human resources (HR) which is indeed a major component in an organization to achieve organizational goals. PT. BRI Bank has a Branch in the City of Sigli which is one of the cities in Indonesia at the western end. So that management activities can run well, of course PT. BRI Bank Sigli branch must have employees who are knowledgeable and also highly skilled and can manage their organizations to operate optimally. The work environment greatly affects employees in loving their work, increasing their competence and influencing one's attachment to be involved in their work (work engagement).

In the current era work engagement has become an important topic for organizations and companies where work engagement has been the subject of many management experts in recent years. Work engagement can be expressed as a motivation and center of positive thoughts related to work. According to(Saks, 2006)Work engagement is also related to individual attitudes, intentions and behavior. Therefore, employees tend to be more attached to the organization where they take shelter and have a low tendency to leave the organization and try to improve their performance.

Individual performance at PT. BRI Bank Sigli Branch is a result of work in quality and quantity that can be achieved by employees of PT. Bank BRI Sigli Branch in accordance with the field of work and its responsibilities. Based on observations that the author has made at PT. BRI Bank Sigli Branch, apparently the employees at PT. BRI Bank Sigli Branch until now there are still many who have not been able to perform as expected by their leaders and also have not been able to provide optimal satisfaction to the people who are their customers. The performance of employees is not yet maximized due to the still low job embeddedness. The phenomenon is related to job embeddedness of employees at PT. BRI Bank Sigli Branch which is still low can be seen from the many employees who still do not want to get involved in work because they feel unable to carry out work that is not in accordance with their job specifications. This will certainly affect the achievement of their performance and have implications for the performance of PT. BRI Bank Sigli Branch.

Then in addition to job embeddedness, one of the problems currently affecting the low performance of employees of PT. BRI Bank Sigli Branch lies in the leadership factor which has not been fully able to improve employee performance and organize all potential resources to achieve organizational goals. The leader has a very important role in the organization to develop and run all the wheels of the organization's operations in order to achieve organizational goals that have been set in the planning, and the success and success of an organization both as a whole and in groups is very dependent on the quality of leadership carried out in the organization. Furthermore, the leader in the organization must of course master about the organization, master the knowledge related to the organization, and can also control the people in the organization and can provide motivation to its employees. Leadership that can foster and develop employee work motivation is leadership that can produce the confidence of its employees as they carry out their respective duties. But in reality, at PT. BRI Bank Sigli Branch still arises a dissatisfaction that is seen from the existence of an attitude and behavior of employees who demand that the work they do must be in accordance with the competencies they 


\section{International Journal of Business Management and Economic Review}

Vol. 3, No. 05; 2020

ISSN: 2581-4664

have. An employee's individual motivation is certainly strongly influenced by two main factors namely intrinsic and extrinsic factors. Intrinsic factors consist of achievement, self-recognition, the nature of work responsibilities and career development while the extrinsic factors include salary, work environment, work relationship.

\section{LITERATURE STUDY}

\section{Organizational Performance}

The success and sustainability of an organization is certainly highly influenced by the performance of its employees. Performance is a picture of the level of achievement of the implementation of tasks in an organization, in its efforts to realize the goals, objectives, mission, and vision of the organization(Bastian, 2014). The concept of performance is widely expressed as the level of achievement of results. Performance describes an outcome (output) from a particular process that has been carried out by all components in the organization against a particular source used (input)(Nofriansyah, 2018). In other words, performance is the result of a series of process activities that have been carried out to achieve organizational goal.

An organization is said to have high performance if the organization is able to produce planned performance on improving quality by utilizing great human resources. According to(Sinaga \& Sinambela, 2013)Organizational performance is expressed as an effectiveness that occurs in the organization as a whole to meet the needs that have been determined from each group concerned through systematic efforts and can continuously improve the organization's ability to achieve their needs effectively. According to (Sobandi et al., 2006)Organizational performance is something that has been achieved by the organization within a certain time period, related to input, output, outcome, benefits, and impact.

Referring to the Menpan Decree Number 63 / KEP / M. PAN / 7/2003, it can be interpreted that the relevant, valid and reliable service element is a benchmark in providing services to the community, especially in organizations that are included in the community service sector. In this study, the indicators used consisted of 10 indicators out of 14 recommended by the Decree of the Menpan Number 63 / KEP / M. PAN / 7/2003, namely: (1) Service procedures, (2) Service requirements, (3) Discipline of officers, (4) Officer responsibilities, (5) Speed of service, (6) Courtesy and friendliness of officers, (7) Certainty service costs, (8) Certainty of service schedules, (9) Environmental security and (10) Service security.

\section{Work Engagement}

Work engagement is interpreted as an emotional and intellectual commitment to the organization(Macey \& Schneider, 2008). (Robbins \& Judge, 2014)provide a view of work engagement, that is, an individual or employee who is at a good level of work engagement in his job is if the employee can identify himself psychologically with his work, and considers his performance important for himself, other than for the organization. Then obey(Mujiasih, 2015)work engagement is an illusory power that can motivate employees to improve performance at a higher level, this energy can be in the form of commitment to the organization, a sense of work and pride, more effort (time and energy), enthusiasm and interest, and commitment in carrying out work assigned.

According(Albrecht, 2010)explain the dimensions or components contained in the work engagement and also an explanation of the indicators of each dimension are: 
Vol. 3, No. 05; 2020

ISSN: 2581-4664

(a) Vigor, is a strong outpouring of energy and mentality at work, the courage to make every effort to complete a job, and persevere in facing difficulties at work. Also, the willingness to invest all effort in a job, and persevere despite difficulties. Indicators (1) Know what to expect, (2) Have work equipment and (3) Have the opportunity.

(b) Dedication, feeling strongly involved in a job and experiencing a sense of meaningfulness, enthusiasm, pride, inspiration and challenges. Indicators (1) Receive awards, (2) leadership concern, (3) There is encouragement, (4) Clarity of vision and mission and (5) Having colleagues.

(c) Absorption, in working employees always concentrate fully and seriously on a job. When working time seems to pass so quickly and find difficulty in separating himself from work. The indicators are (1) There are places to ask questions, (2) Have learning opportunities.

\section{Job Embeddedness}

(Mitchell \& Lee, 2001)describes the concept of job embeddedness, which is something that illustrates the extent to which an employee is tied to his work and the organization where he works due to the accumulation of influence from aspects that originate from the work (on-thejob) or from outside the job (off-the-job) the. The stronger a relationship and compatibility between an individual or employee and their environment within the organization and with the community outside the organization, and the greater the sacrifice that must be made if leaving the organization or the surrounding community, the stronger the individual or employee perceives himself bound with the organization and with the work(Polii, 2015).

Job embeddedness indicator according to (Mitchell \& Lee, 2001)consists of: (1) Fit to organization, (2) Fit to community, (3) Link Organization, (4) Link to community, (5) Organization sacrifice, (6) community sacrifice.

\section{Leadership}

(Schuler \& Jackson, 2014)describe Leadership as the ability of a person to convince others so that they can direct others to the maximum to carry out certain tasks.(Noe, Hollenbeck, Gerhart, \& Wright, 2015)explains that leadership means the relationship between one person namely the leader, which influences the other party to be able to work together in an effort to do related tasks, to achieve the things the leader wants.

Leadership indicators according to(Schuler \& Jackson, 2014)consists of: (1) ability to read situations owned by a leader, (2) Giving awards given by leaders to employees, (3) Creativity possessed by a leader, (4) leaders are able to create work discipline and (5) leaders able to provide guidance to members of the organization.

\section{Motivation}

(Gibson, Ivancevic, \& Konopaske, 2012)conveying his views on motivation, motivation is a concept that is used to explain the forms of impulses that arise in a person or individual who further move and also direct their behavior. While(Moeheriono, 2014)revealed that an employee's work motivation will affect one's performance. Motivation is an impetus that comes from two directions, namely motivation that arises from within an employee (internal motivation) or motivation comes from outside someone (external motivation).(Hasibuan, 2014)revealed that motivation as a driving force that gives rise to the enthusiasm of one's work, 


\section{International Journal of Business Management and Economic Review}

Vol. 3, No. 05; 2020

ISSN: 2581-4664

so that someone also wants to cooperate with others, work effectively and be integrated with all their power and efforts to achieve satisfaction.

According to(Robbins \& Judge, 2014), the indicators of work motivation are as follows: (1) Life security for employees, (2) security guarantees in carrying out work, (3) appreciation for those who excel, (4) pride in being employees and (5) attitude for self-actualizing.

\section{Research Paradigm}

Based on the discussion of the problem and research literature, the researcher formulates the paradigm and research hypothesis as follows.

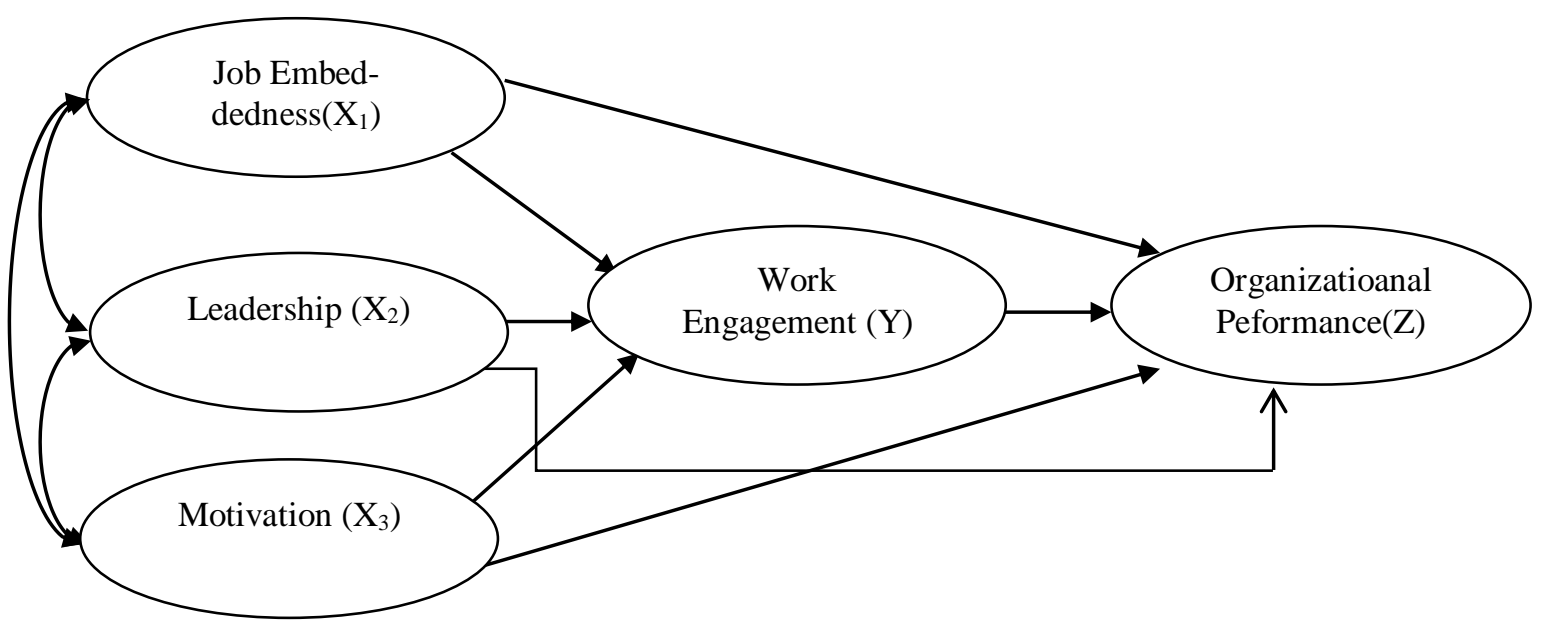

Figure 1. Research Model

Ha1 : Job embeddedness affects PT. BRI Bank Sigli Branch.

Ha2 : Leadership influences PT. BRI Bank Sigli Branch.

Ha3 : Work motivation affects the work engagement of PT. BRI Bank Sigli Branch.

Ha4 : Job embeddedness affects the performance of PT. BRI Bank Sigli Branch.

Ha5 : Leadership influences the performance of PT. BRI Bank Sigli Branch.

Ha6 : Work motivation affects the performance of PT. BRI Bank Sigli Branch.

Ha7 : Work engagement affects the performance of PT. BRI Bank Sigli Branch.

Ha8 : Employee work engagement mediates the effect of job embeddedness on the performance of PT. BRI Bank Sigli Branch.

Ha9 : Employee work engagement mediates the influence of leadership on the performance of PT. BRI Bank Sigli Branch.

Ha10 : Work engagement employees mediate the effect of work motivation on organizational performance through PT. BRI Bank Sigli Branch.

\section{Research Methods}

This study uses objects, namely PT. BRI Bank Sigli Branch. As for the research variables are job embeddedness, leadership, work motivation, work engagement and performance of PT. BRI Bank Sigli Branch. The study population was all employees of PT. BRI Bank Sigli Branch 


\section{International Journal of Business Management and Economic Review}

Vol. 3, No. 05; 2020

ISSN: 2581-4664

totaling 127 people. Sampling was done by census technique on all employees at PT. BRI Bank Sigli Branch. Data collected through the use of questionnaires. The list of questions is asked and assessed using a Likert scale. Data were analyzed using Structural Equation Modeling (SEM) techniques, through the use of Amos software. The SEM equation model is a combination of statistical techniques that can test a series of relatively complex relationships simultaneously(Hair, Hult, Ringle, \& Sarstedt, 2016).SEM is able to enter latent variables into the analysis. Before testing the hypothesis, confirmatory factor analysis (CFA). CFA in SEM needs to be done to ensure that the indicators are fit(Silva \& Alwi, 2008). To test mediation variables, this study uses the Sobel test.

\section{RESULTS AND DISCUSSION}

Structural model analysis that explains the test of influence between variables is presented in the following path diagram.

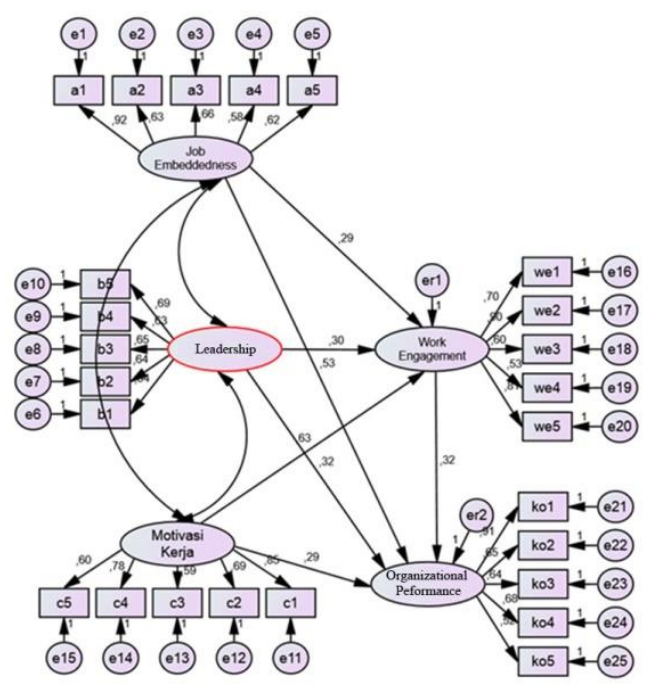

Figure 2. Hypothesis Test Results

Analysis of the influence between variables contained in Figure 2 above needs to be done to find out the extent of the strength of the influence between the constructs, both the influence with the direct impact, and the indirect effect, in accordance with the research hypothesis. For direct effects, it can be seen from the significance and coefficient values of all lines in the form of arrows that have one end. For effects that are indirect (indirect effect) is the influence arising through an intermediate variable(Ferdinand, 2014), which can also be seen from the significance and coefficient values. Then it can be analyzed as follows.

\section{Direct Effect and Coefficient}

The results of testing the full model for testing the direct effect hypothesis after fulfilling the SEM assumptions, are more clearly found in the following table: 
Vol. 3, No. 05; 2020

ISSN: 2581-4664

Table 1. Hypothesis Testing Results

\begin{tabular}{|c|c|c|c|c|c|c|c|}
\hline & & & $\begin{array}{l}\text { Estimat } \\
\mathrm{e}\end{array}$ & $\begin{array}{l}\text { S.E } \\
\text {. }\end{array}$ & C.R. & $\mathrm{P}$ & $\begin{array}{l}\text { Labe } \\
1\end{array}$ \\
\hline Work_Engagement & $<---$ & $\begin{array}{l}\text { Job_Embeddednes } \\
\text { s }\end{array}$ & .290 & .042 & 6.902 & $\begin{array}{l}0.00 \\
0\end{array}$ & \\
\hline Work_Engagement & $<---$ & Leadership & .305 & .049 & 6.259 & $\begin{array}{l}0.00 \\
0\end{array}$ & \\
\hline Work_Engagement & $<---$ & Motivation & .635 & .089 & 7.114 & $\begin{array}{l}0.00 \\
0\end{array}$ & \\
\hline $\begin{array}{l}\text { Organizational_Peforman } \\
\text { ce }\end{array}$ & $<---$ & $\begin{array}{l}\text { Work_Engagemen } \\
\mathrm{t}\end{array}$ & .320 & .048 & 6.640 & $\begin{array}{l}0.00 \\
0\end{array}$ & \\
\hline $\begin{array}{l}\text { Organizational_Peforman } \\
\text { ce }\end{array}$ & $<---$ & $\begin{array}{l}\text { Job_Embeddednes } \\
\text { s }\end{array}$ & .538 & .091 & 5.923 & $\begin{array}{l}0.00 \\
0\end{array}$ & \\
\hline $\begin{array}{l}\text { Organizational_Peforman } \\
\text { ce }\end{array}$ & $<---$ & Leadership & .322 & .046 & 7.068 & $\begin{array}{l}0.00 \\
0\end{array}$ & \\
\hline $\begin{array}{l}\text { Organizational_Peforman } \\
\text { ce }\end{array}$ & $<---$ & Motivation & .298 & 049 & 6.134 & $\begin{array}{l}0.00 \\
0\end{array}$ & \\
\hline
\end{tabular}

Source: Questionnaire / Primary Data, 2020 (processed)

From table 1 above, for direct influence can be explained per hypothesis is :

\section{H1 : The Effect of Job Embeddedness on Work Engagement of PT. BRI Bank Sigli Branch}

In the $\mathrm{H} 1$ test results, the effect of job embeddedness on employee engagement shows a CR value of 6.902 and a probability value of 0,000 . The test results obtained have fulfilled the requirements to receive $\mathrm{H} 1$, namely the $\mathrm{CR}$ value of 6.902 which is already higher than 1.97 and the probability value that is already lower than 0.05. Therefore it can be explained that job embeddedness affects the work engagement of employees at PT. BRI Bank Sigli Branch. This indicates that the better job embeddedness will cause an increase in employee engagement at PT. BRI Bank Sigli Branch.

These results are aligned and consistent with research conducted by(Ringl, 2013)which states organizational commitment is positively related to work involvement. Furthermore, nonworking aspects of one's living space (community and community sacrifice) are related to work involvement. Thus the better job embeddedness owned by employees will have an impact on increasing the work engagement of employees of PT. BRI Bank Sigli Branch.

Furthermore, the coefficient value (in the estimate column) of influence explains the magnitude of the effect that occurs if the exogenous variable influences the endogenous variable. This value is an excerpt from the estimated value of Standardized at SEM. From the table above, the value of the effect coefficient resulting from the job embeddedness variable to the work engagement variable is 0.290 . This means that if there is an increase in job embeddedness by 1 unit, it will increase work engagement by 0.290 units. 


\section{International Journal of Business Management and Economic Review}

Vol. 3, No. 05; 2020

ISSN: 2581-4664

\section{H2 : Effect of Leadership on Employee Work Engagement of PT. BRI Bank Sigli Branch}

In the $\mathrm{H} 2$ test results, the influence of leadership on employee work engagement shows a $\mathrm{CR}$ value of 6.259 and a probability value of 0,000 . The test results obtained meet the requirements to receive $\mathrm{H} 3$, namely a $\mathrm{CR}$ value of 6.259 which is already higher than 1.97 and a probability value that is already lower than 0.05 . Therefore it can be explained that leadership influences employee engagement at PT. BRI Bank Sigli Branch. This indicates that the presence of leadership in accordance with the conditions of the work environment will lead to an increase in employee engagement at PT. BRI Bank Sigli Branch.

These results are aligned and consistent with research conducted by(Brahmasari \& Suprayetno, 2008)which states that leadership can increase employee engagement. The results of this study are also in line with the theory developed by(Parlinda \& Wahyuddin, 2004)which states that the leadership factor has an impact on increasing employee engagement in achieving the performance expected by the organization in this case PT. BRI Bank Sigli Branch.

Furthermore, the coefficient value (in the estimate column) of influence explains the magnitude of the effect that occurs if the exogenous variable influences the endogenous variable. This value is an excerpt from the estimated value of Standardized at SEM. From the table above, the value of the coefficient of influence resulting from the leadership variable on the work engagement variable is 0.305 . This means that if there is an increase in leadership by 1 unit, it will increase work engagement by 0.305 units.

\section{H3 : The Effect of Work Motivation on Employee Work Engagement of PT. BRI Bank Sigli Branch}

On the $\mathrm{H} 3$ test results, the effect of work motivation on employee work engagement shows a CR value of 7.114 and a probability value of 0,000 . The test results obtained already meet the requirements for accepting $\mathrm{H} 2$, namely a $\mathrm{CR}$ value of 7.114 which is already higher than 1.97 and a probability value that is already lower than 0.05 . Therefore it can be explained that work motivation will affect employee engagement at PT. BRI Bank Sigli Branch. This reveals that the higher work motivation possessed by employees will have an influence in increasing employee engagement, because employees who already feel motivated will always try to increase work engagement especially in achieving organizational goals.

These results are aligned and consistent with research conducted by(Brahmasari \& Suprayetno, 2008)who found that employee work motivation can increase employee loyalty. Also consistent with the theory developed by(Robbins \& Judge, 2014)Motivation is a process that influences the intensity, direction and duration of an individual's efforts towards achieving goals. According to(Hasibuan, 2016)the purpose of providing motivation is to maintain employee loyalty and employee stability, meaning that motivation has a positive influence on the length of time the employee works.

Furthermore, the coefficient value (in the estimate column) of influence explains the magnitude of the effect that occurs if the exogenous variable influences the endogenous variable. This value is an excerpt from the estimated value of Standardized at SEM. From the table above, the value of the coefficient of influence resulting from the variable work motivation to the variable work engagement is equal to 0.635. This means that if there is an increase in work motivation by 1 unit, it will increase work engagement by 0.635 units. 


\section{International Journal of Business Management and Economic Review}

Vol. 3, No. 05; 2020

ISSN: 2581-4664

\section{H4 : The Effect of Job Embeddedness on Organizational Performance of PT. BRI Bank Sigli Branch}

On the $\mathrm{H} 4$ test results, the effect of job embeddedness on organizational performance shows a CR value of 5.923 and a probability value of 0,000 . The test results obtained meet the requirements to receive $\mathrm{H} 4$, namely a $\mathrm{CR}$ value of 5.923 which is already higher than 1.97 and a probability value that is already smaller than 0.05 . Therefore it can be explained that job embeddedness will affect the organizational performance of PT. BRI Bank Sigli Branch. Convenient job embeddedness will have an effect that is in line with the organizational performance improvement of PT. Bank BRI Sigli Branch especially in improving services to customers at PT. BRI Bank Sigli Branch.

These results are aligned and consistent with research conducted by(Takawira, Coetzee, \& Schreuder, 2014)who found that job embeddedness will have a positive impact on improving organizational performance in PT. BRI Bank Sigli Branch. The results of this research have also been in line with research conducted by(Wijayanto \& Kismono, 2004)which states that job embeddedness can significantly improve organizational performance.

Furthermore, the coefficient value (in the estimate column) of influence explains the magnitude of the effect that occurs if the exogenous variable influences the endogenous variable. This value is an excerpt from the estimated value of Standardized at SEM. From the table above, the value of the coefficient of influence resulting from the variable job embeddedness to the performance variable is 0.538 . This means that if there is an increase in job embeddedness of 1 unit, it will increase performance by 0.538 units.

\section{H5 : Effect of Leadership on Organizational Performance of PT. BRI Bank Sigli Branch}

On the $\mathrm{H} 5$ test results, the influence of leadership on organizational performance shows a CR value of 7.068 and a probability value of 0,000 . The test results obtained already meet the requirements for receiving $\mathrm{H} 5$, namely a $\mathrm{CR}$ value of 7.068 which is already higher than 1.97 and a probability value that is already smaller than 0.05 . Thus it can be explained that leadership in accordance with employee conventions and the work environment will have a parallel effect on improving the organizational performance of PT. BRI Bank Sigli Branch, so that leadership in accordance with the characteristics of employees will have a positive impact or influence on improving organizational performance of PT. BRI Bank Sigli Branch.

These results are aligned and consistent with research conducted by(Wibowo \& Susilowati, 2010)who found that leadership can have an influence on improving organizational performance. The results of this study are also in line with research conducted by(Parlinda \& Wahyuddin, 2004)which explains his findings that leadership in a public organization will have a positive impact on improving organizational performance.

Furthermore, the coefficient value (in the estimate column) of influence explains the magnitude of the effect that occurs if the exogenous variable influences the endogenous variable. This value is an excerpt from the estimated value of Standardized at SEM. From the table above, the value of the coefficient of influence resulting from the leadership variable on the performance variable is 0.322 . This means that if there is an increase in leadership by 1 unit, it will increase performance by 0.322 units. 
Vol. 3, No. 05; 2020

ISSN: 2581-4664

\section{H6 : Effect of Work Motivation on Organizational Performance of PT. BRI Bank Sigli Branch.}

On the $\mathrm{H} 6$ test results, the influence of work motivation on organizational performance shows a CR value of 6.134 and a probability value of 0,000 . The test results obtained meet the requirements to receive $\mathrm{H6}$, namely the $\mathrm{CR}$ value of 6.134 which is already higher than 1.97 and the probability value that is already lower than 0.05 . Therefore it can be explained that work motivation will affect the organizational performance of PT. BRI Bank Sigli Branch. Work motivation owned by employees will also have a positive and significant impact on improving organizational performance of PT. BRI Bank Sigli Branch.

These results are in harmony and are consistent with research conducted by(Mariani \& Sariyathi, 2017)which revealed that work motivation has an influence on improving organizational performance. The current research results are also supported by theory(Moeheriono, 2014), An employee's work motivation will affect his performance, where work motivation arises from the motivation that exists in an employee (internal motivation) or motivation that comes from outside the employee concerned (external motivation).

Furthermore, the coefficient value (in the estimate column) of influence explains the magnitude of the effect that occurs if the exogenous variable influences the endogenous variable. This value is an excerpt from the estimated value of Standardized at SEM. From the table above, the value of the coefficient of influence resulting from the work motivation variable to the performance variable is 0.298 . This means that if there is an increase in work motivation by 1 unit, it will increase performance by 0.298 units.

\section{H7 : The Effect of Employee Work Engagement on PT. BRI Bank Sigli Branch}

On the results of the $\mathrm{H} 7$ test, the effect of employee engagement on organizational performance shows a CR value of 6.640 and a probability of 0.000 . The test results obtained meet the requirements to receive $\mathrm{H} 7$, namely a $\mathrm{CR}$ value of 6.640 which is already higher than 1.97 and a probability value that is already lower than 0.05 . Therefore it can be explained that employee engagement will affect the organizational performance of PT. BRI Bank Sigli Branch. The results of this study imply that the higher level of work engagement possessed by employees will have an influence in improving the organizational performance of PT. BRI Bank Sigli Branch. The results of this study are consistent with research conducted by(Kadarisman, 2016)and(Utami \& Sukmawat, 2018)which states that work engagement has an influence on improving organizational performance.

Furthermore, the coefficient value (in the estimate column) of influence explains the magnitude of the effect that occurs if the exogenous variable influences the endogenous variable. This value is an excerpt from the estimated value of Standardized at SEM. From the table above, the value of the coefficient of influence resulting from the work engagement variable to the performance variable is 0.320 . This means that if there is an increase in work engagement by 1 unit, it will increase performance by 0.320 units.

\section{Effect of Mediation and its Coefficients}

The results of testing the hypothesis of the current research mediation model which can be seen from the significance and coefficient values reveal the evidence of the effect and the 
International Journal of Business Management and Economic Review

Vol. 3, No. 05; 2020

ISSN: 2581-4664

magnitude of the influence between the variables indirectly, as also summarized in Table 2 below.

Table 2. Coefficient of Mediation Influence

\begin{tabular}{|l|l|l|ll|l|l|}
\hline No & Description & Direct & Indirect & $\begin{array}{l}\text { Sobel } \\
\text { test } \\
\text { (Sig. } \\
\text { Value) }\end{array}$ & Information \\
\hline 1. & $\begin{array}{l}\text { The effect of job embeddedness } \\
\text { on organizational performance }\end{array}$ & $\begin{array}{l}(0.538)^{2} \\
=0.289\end{array}$ & $\begin{array}{l}0.290 \\
0.320 \\
=\mathbf{0 . 0 9 3}\end{array}$ & $\mathrm{x}$ & 0.000 & Significant \\
\hline 2. & $\begin{array}{l}\text { The influence of leadership on } \\
\text { organizational performance }\end{array}$ & $\begin{array}{l}(0.322)^{2} \\
=0.104\end{array}$ & $\begin{array}{l}0.305 \\
0.320 \\
=\mathbf{0 . 0 9 8}\end{array}$ & $\mathrm{x}$ & 0.000 & Significant \\
\hline 3. & $\begin{array}{l}\text { The effect of leadership on } \\
\text { organizational performance }\end{array}$ & $\begin{array}{l}(0.298)^{2} \\
=0.089\end{array}$ & $\begin{array}{l}0.635 \\
0.320 \\
\mathbf{= 0 . 2 0 3}\end{array}$ & $\mathrm{x}$ & 0.000 & Significant \\
\hline
\end{tabular}

Source: Primary Data, 2020 (processed).

From the table above it can be seen that the Sobel test is used as proof of the significance of the research mediation model. There is also an indirect effect coefficient number, which is the result of the multiplication of the related direct coefficients. For an explanation, then the description per hypothesis can be as follows.

H8 :Work engagement mediates the effect of job embeddedness on organizational performance of PT. BRI Bank Sigli Branch

From the Sobel test conducted, the results show that work engagement significantly mediates the effect of Job embeddedness on organizational performance. The mediating effect of the work engangement is proven to have a partial role as a mediator, because in addition to Job embeddedness it can directly affect performance, but it can also affect indirectly through work engagement. The coefficient of the direct effect of the job embeddedness variable on work engagement is 0.290 . While the coefficient of the influence of job embeddedness on organizational performance through work engagement variable is 0.093 . This means that if there is an increase in job embeddedness of 1 unit, it will improve performance through work engagement of 0.093 units. Then it can be explained that to improve the organizational performance of PT. BRI Bank Sigli Branch, the leadership must be able to improve the job embeddedness, especially those related to comfort in carrying out work.

\section{H9 :Work Engagement Mediates the Effect of Leadership on Organizational Performance of PT. BRI Bank Sigli Branch}

From the Sobel test conducted, the results show that work engagement significantly mediates the effect of leadership on organizational performance. The mediating effect of the work engangement is proven to have a partial role as a mediator, because in addition to leadership it can directly affect performance, but it can also affect indirectly through work 


\section{International Journal of Business Management and Economic Review}

Vol. 3, No. 05; 2020

ISSN: 2581-4664

engagement. The coefficient of the direct influence of the leadership variable on work engagement is 0.305 . While leadership has an influence on organizational performance through work engagement variable is 0.098 . This means that if there is an increase in leadership by 1 unit, it will improve performance through work engagement by 0.098 units. Then it can be explained that to improve the organizational performance of PT. BRI Bank Sigli Branch, then of course the organization must change leadership behavior for the better, so that leadership in this case the head of PT. BRI Bank Sigli Branch can be accepted by all employees and customers at PT. BRI Bank Sigli Branch.

\section{H10 : Work engagement mediates the effect of motivation on organizational performance of PT. BRI Bank Sigli Branch}

From the Sobel test conducted, the results show that work engagement significantly mediates the effect of work motivation on organizational performance. The mediating effect of the work engangement is proven to have a partial role as a mediator, because in addition to work motivation can affect performance directly, but also can affect indirectly through work engagement. The coefficient of the direct influence of the motivational variable on work engagement is 0.635 . While the effect of work motivation on organizational performance through work engagement variables is 0.203 . This means that if there is an increase in work motivation by 1 unit, it will improve performance through work engagement by 0.203 units. Then it can be explained that to improve the organizational performance of PT. BRI Bank Sigli Branch, the leadership must be able to increase employee work motivation by giving awards to employees who achieve high work performance or giving praise to employees who can achieve the specified work.

\section{CONCLUSIONS}

The results of research at PT. BRI Bank Sigli Branch proved that job embeddedness obtained an average value of 4.20 , leadership worth 4.19 , work motivation valued at 4.20 , work engagement valued at 4.25 and organizational performance valued at 4.21 , so that all variables were descriptive has been going well, job embeddedness affects work engagement, leadership also influences work engagement, work motivation influences work engagement, Job embeddedness influences organizational performance, Leadership influences organizational performance, Work motivation owned by employees influences organizational performance Work engagement has an influence on improving organizational performance, mediating work engagement on the influence of job embeddedness on organizational performance, work engagement mediates the influence of leadership on organizational performance, and work engagement mediates the effect of work motivation on organizational performance. The results of this study show the importance of job embeddedness, leadership, and work motivation in improving organizational performance of PT. BRI Bank Sigli Branch .. The findings of this study can also be interpreted that to ensure high organizational performance, policy makers at PT Bank BRI must design the right strategy that focuses on improving work engangement through job embeddedness, leadership, and work motivation. Future research writers should be able to add more variables or build new constructs based on the findings of this study.

Some strategy recommendations were born from research findings. In order to improve work engagement and organizational performance of PT. BRI Bank Sigli Branch, based on the 


\section{International Journal of Business Management and Economic Review}

Vol. 3, No. 05; 2020

ISSN: 2581-4664

perspective of job embeddedness, what needs to be done is that the organization must improve the ability of employees to maintain networks in different institutions, so that inter-banking relations are maintained better. In addition, by taking into account the variable increase in work engagement and organizational performance based on the perspective of leadership, then what needs to be done by the leader is to explain in providing input and criticism of every work carried out by employees.

Related to work motivation issues in order to improve work engagement and organizational performance, what is needed to be done is to provide a guarantee of life from the organization to make me motivated to work better. To increase the work engagement of PT. BRI Bank Sigli Branch as a whole, then what needs to be considered by the organization is that each employee must have good and adequate work equipment to support the achievement of organizational performance. Meanwhile, to improve organizational performance, it is very important for leaders to pay attention that the organization must carry out all service activities in accordance with established procedures, and run smoothly, so that the organization becomes better.

\section{REFERENCES}

Albrecht, S. L. (2010). Research and Practice. Handbook of Employee Engagement Perspective. In Issues. UK: MGP Books Group. Cheltenham, UK・ Northampton, MA, USA.

Bastian, I. (2014). Sistem Pengendalian Manajemen Sektor Publik Mempertahankan Kepentingan Masyarakat. Jakarta. Penerbit Salemba Empat.

Brahmasari, I. A., \& Suprayetno, A. (2008). Pengaruh Motivasi Kerja, Kepemimpinan dan Budaya Organisasi Terhadap Kepuasan Kerja Karyawan serta Dampaknya pada Kinerja Perusahaan (Studi kasus pada PT. Pei Hai International Wiratama Indonesia). Jurnal Manajemen Dan Kewirausahaan, 10(2), 124-135.

Ferdinand, A. (2014). Metode Penelitian Manajemen (Edisi 5). Semarang: Universitas Diponegoro.

Gibson, J., Ivancevic, J., \& Konopaske, R. (2012). Organizations: Behavior, Structure, Processes (14th ed.). New York: Mc Graw Hill.

Hair, J. F., Hult, G. T. M., Ringle, C., \& Sarstedt, M. (2016). A Primer on Partial Least Squares Structural Equation Modeling (PLS-SEM) (2nd ed.). Thousand Oaks: Sage Publications, Inc.

Hasibuan. (2014). Manajemen Sumber Daya Manusia. In Manajemen Sumber Daya Manusia (Revisi). Jakarta: Bumi Aksara.

Hasibuan, M. S. (2016). Buku Manajemen Sumber Daya Manusia (Revisi). Jakarta: Bumi Aksara.

Kadarisman, M. (2016). Manajemen kompensasi (Cetakan ke). Jakarta: Raja Grafindo Persada. Macey, W., \& Schneider, B. (2008). The Meaning of Employee Engagement. Industrial and Organizational Psychology, 1(1), 3-30. https://doi.org/10.1111/j.1754-9434.2007.0002.x

Mariani, L. M. I., \& Sariyathi, N. K. (2017). Pengaruh Motivasi, Komunikasi Dan Disiplin Kerja Terhadap Kinerja Karyawan Warung Mina Peguyangan Di Denpasar. E-Jurnal Manajemen Unud, 6(7), 3540-3569.

Mitchell, T., \& Lee, T. (2001). The unfolding model of voluntary turnover and job embeddedness: Foundations for a comprehensive theory of attachment. Research in 


\section{International Journal of Business Management and Economic Review}

Vol. 3, No. 05; 2020

ISSN: 2581-4664

Organizational Behavior, 23, 189-246. https://doi.org/https://doi.org/10.1016/S01913085(01)23006-8

Moeheriono. (2014). Pengukuran Kinerja Berbasis Kompetensi (Revision). Jakarta: Raja Grafindo Persada.

Mujiasih, E. (2015). Hubungan Antara Persepsi Hubungan Organisasi (Perceived Organizational Support) dengan Keterikatan Karyawan. Jurnal Psikologi, 14(1), 40-51. https://doi.org/https://doi.org/10.14710/jpu.14.1.40-51

Noe, R., Hollenbeck, J., Gerhart, B., \& Wright, P. (2015). Fundamentals of Human Resource Management (6th ed.). New York: McGraw-Hill.

Nofriansyah, D. (2018). Penelitian Kualitatif: Analisis Kinerja Lembaga Pemberdayaan Masyarakat Kelurahan. Yogyakarta: Deepublish.

Parlinda, V., \& Wahyuddin, M. (2004). Pengaruh Kepemimpinan, Motivasi, Pelatihan, Dan Lingkungan Kerja Terhadap Kinerja Karyawan Pada Perusahaan Daerah Air Minum Kota Surakarta. Jurnal Pascasarjana Universitas Muhammadiyah Surakarta. Retrieved from http://eprints.dinus.ac.id/5077/1/11392.pdf

Polii, L. R. G. (2015). Analisis Keterikatan Karyawan Terhadap Pekerjaandan Lingkungan Kerja Terhadap Kepuasan Kerja Dan Turnover Intentions Karyawan Di Rumah Sakit Siloam Manado. Jurnal EMBA, 3(4), 178-190.

Ringl, R. W. (2013). The Relationship between Job Embeddedness and Work Engagement. San José State University.

Robbins, S. P., \& Judge, T. A. (2014). Buku Perilaku Organisasi Buku 2 (Edisi ke-1; alih bahasa D. Angelica, Ed.). Salemba Empat.

Saks, A. M. (2006). Employee engagement: Antecendents and consequences. Journal of Managerial Psychology, 21(7), 600-619.

Schuler, R., \& Jackson, S. E. (2014). Human resource management andorganizational effectiveness:yesterday and today. Journal of Organizational Effectiveness: People AndPerformance, 1(1), 35-55. https://doi.org/10.1108/JOEPP-01-2014-0003

Silva, R. V. Da, \& Alwi, S. F. S. (2008). Online brand attributes and online corporate brand images. European Journal of Marketing, 42(9), 1039-1058. https://doi.org/https://doi.org/10.1108/03090560810891136

Sinaga, T., \& Sinambela, M. (2013). Pengaruh Stres Kerja Terhadap Motivasi Dan Kinerja Auditor Pada Kantor Akuntan Publik Di Kota Medan. Jurnal Akuntansi, XVII(1), 75-83.

Sobandi, B., Sedarmayanti, Utomo, T. W. W., Dawud, J., Nugraha, \& Kusumah, I. B. (2006). Desentralisasi dan tuntutan penataan kelembagaan daerah. Bandung: Humaniora.

Takawira, N., Coetzee, M., \& Schreuder, D. (2014). Job embeddedness, work engagement and turnover intention of staff in a higher education institution: An exploratory study. $S A$ Journal of Human Resource Management, 12(1), 1-10. https://doi.org/https://doi.org/10.4102/sajhrm.v12i1.524

Utami, A., \& Sukmawat, A. (2018). Pengaruh Kompetensi terhadap Kepuasan Kerja dan Work EngagementKaryawan UKM Kluster Hasil Pengolahan Perikanan di Bogor. Jurnal Manajemen Dan Organisasi, 9(1), 10-21.

Wibowo, E., \& Susilowati, W. (2010). Pengaruh kepemimpinan, organizational citizenship behaviour, dan komitmen organisasional terhadap kepuasan kerja pegawai. Jurnal Ekonomi Dan Kewirausahaan, 10(1), 66-73. 
International Journal of Business Management and Economic Review

Vol. 3, No. $05 ; 2020$

ISSN: 2581-4664

Wijayanto, B. R., \& Kismono, G. (2004). The Effect Of Job Embeddedness On Organizational Citizenship Behavior: The Mediating Role Of Sense Of Responsibility. Gadjah Mada International Journal of Business, 4(3), 335-354. https://doi.org/https://doi.org/10.22146/gamaijb.5554 